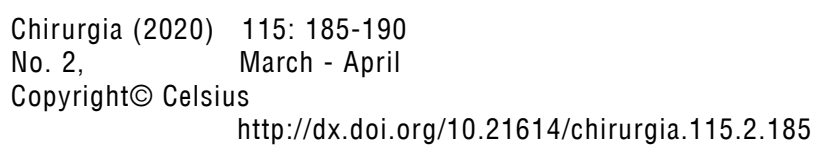

\title{
What are the Particularities of Pancreatic Surgery in the Cirrhotic Patient?
}

\author{
Lilian Schwarz, Jean-Marc Regimbeau, Lionel Rebibo \\ 'Department of digestive surgery, CHU Rouen, 76000 Rouen, France \\ ${ }^{2}$ Department of digestive surgery, CHU Amiens, 80054 Amiens, France \\ ${ }^{3}$ Department of digestive surgery, Hôpital Bichat, APHP, Paris, France
}

Corresponding author:

Lionel Rebibo, MD

Department of digestive surgery

Hopital Bichat, APHP

46 Rue Henri Huchard, 75018 Paris

E-mail: rebibo.lionel@aphp.fr

\section{Rezumat}

Care sunt particularitățile chirurgiei pancreatice la pacienții cirotici

Obiectivul acestei lucrări este de a trece în revistă întreaga literatură chirurgicală pancreatică, pentru a defini în mod cât mai adecvat indicațiile chirurgicale şi specificul managementului lor terapeutic. Studiul se bazează pe publicațiile din PubMed şi Google Scholar în limbile franceză şi engleză din perioada ianuarie 1995 iunie 2015. Cele două indicații principale studiate aici sunt tratamentul cancerului şi al pancreatitei cronice. Intervenția chirurgicală la pacientul cirotic expune pacientul la un risc mai mare de complicatiii decât pacientul ne-cirotic. Se recomandă utilizarea scorurilor Child-Pugh şi MELD pentru evaluarea riscurilor şi ghidarea deciziilor operative. Clasele B ale scorului Child-Pugh şi o valoare a scorului MELD mai mare decât 15 sunt asociate cu o mortalitate mai ridicată. $\mathrm{Cu}$ toate acestea, dacă pacienții cirotici candidați la o intervenție chirurgicală pancreatică sunt selecționați în mod corespunzător, supraviețuirea de lungă durată pare echivalentă cu cea a grupului necirotic. $\mathrm{Nu} \mathrm{s} \mathrm{s}^{-a}$ raportat niciun factor de risc de supraviețuire pe termen lung. În concluzie, pacienții cirotici candidați la o intervenție chirurgicală pancreatică trebuie să fie selecționați în mod corespunzător, deoarece ciroza expune la un risc mai ridicat de mortalitate postoperatorie.

Cuvinte cheie: ciroză, chirurgie pancreatică, pancreatita cronică 


\section{Abstract}

The objective of this work was to review the entire literature on pancreatic surgery in order to best define the surgical indications and the specifics of their management. The bibliographic research was done on Pubmed over the period from January 1995 to June 2015, using French and English as the languages of publication. The two main indications discussed here are the management of cancer and chronic pancreatitis. Surgery in the cirrhotic patient exposes the patient to a higher risk of complications than in the non-cirrhotic patient. Child-Pugh and MELD scores should be used to assess risk and guide operative decision. Child-Pugh classes B and a MELD score value greater than 15 are associated with higher morbidity and mortality. However, if suitable selection is made of cirrhotic patients who are candidates for pancreatic surgery, long-term survival seems to be equivalent to the non-cirrhotic group. No risk factors for long-term survival have been reported. In conclusion, cirrhotic patients, candidates for pancreatic surgery must be correctly selected, cirrhosis exposes to a higher risk of postoperative morbidity and mortality.

Key words: cirrhosis, pancreatic surgery, chronic pancreatitis

\section{Introduction}

This chapter reports the results of surgical studies conducted in cirrhotic patients requiring pancreatic surgery. Most of the articles published have focused on immediate post-operative complications and/or postoperative mortality. Only cephalic duodenopancreatectomy has been the subject of publications on the subject, and the majority of studies have focused on pancreatic surgery for carcinological purposes. The severity scores for cirrhosis as well as portal hypertension were studied as a risk factor for complications.

\section{Research Carried Out}

\section{Research Strategy and Study Selection Criteria}

A review of the literature data published between January 1995 and August 2015 was conducted using the international databases Pubmed and Google Scholar. Eligible articles address pancreatic surgery in the cirrhotic patient. The following keywords were used: (pancreatic and surgery and liver and cirrhosis), (pancreatic and surgery and cirrhosis), (Frey procedure" and cirrhosis), (Berger procedure" and cirrhosis), (whipple procedure" or "pancreaticoduodenectomy" and cirrhosis), (surgical ampullectomy" and cirrhosis), (distal pancreatectomy" and cirrhosis).
Articles in full, prospective or retrospective texts and books published in French or in English were selected. Clinical cases were excluded from the selection. For each of the selected articles, a manual review of the references mentioned was carried out to identify possible additional studies not referenced in the databases.

\section{Data Extraction and Analysis}

The reviewers extracted the following data from the different studies: first author, date, type of study, number of patients analysed.

The information collected included the surgical indication, the optimization of the patient before surgery, the technical characteristics (abdominal and/or biliary drainage preoperative, the approach, pyloric preservation, the type of anastomosis performed, the use of intraoperative drug therapy), shortterm results (operative data, postoperative data), morbidity and mortality and its risk factors, hepatic function (CHILD - PUGH score; MELD, presence of portal hypertension) and long-term outcomes (survival data, adjuvant therapy, quality of life).

After selection 5 articles were taken into account (3 of level 4 and 2 of level 3) (Table 1). 
Table 1.

\begin{tabular}{lll}
\hline Level of Scientific Evidence Provided by the Literature & Before selection & After selection \\
\hline Level 1 & & \\
High-power randomized controlled trials & & \\
Meta-analysis of randomized controlled trials & & \\
Decision analysis based on well-conducted data & & \\
\hline Level 2 & & \\
Low-power randomized controlled trials & \\
Well-conducted non-randomized comparative studies & \\
Cohort studies & 3 \\
\hline Level 3 & \\
Control case study & \\
\hline Level 4 & \\
Comparative studies with significant biases & \\
Retrospective studies & \\
Case series & \\
Descriptive epidemiological studies & \\
Meta-analysis of retrospective studies & \\
\hline Reviews of retrospective studies & \\
\hline Clinical cases & \\
\hline Books & \\
\hline Opinions / Conferences & \\
\hline
\end{tabular}

\section{Surgical Indications}

Among the 5 studies selected (1-5), 141 patients were operated on with a cephalic duodenopancreatectomy and 1 patient with a caudal splenopancreatectomy, the only gestures reported in the literature between 1995-2005, excluding clinical cases. The indication for pancreatic surgery was tumour in the majority of cases, with 84 pancreatic ductal adenocarcinomas, 31 ampullary adenocarcinomas, 6 duodenal adenocarcinomas, 4 cholangiocarcinomas of the lower third of the main bile duct and 1 cystic tumour. The other 16 patients were operated on for chronic pancreatitis.

The main indication reported in the literature of cephalic duodenopancreatectomy in cirrhotic patients was tumour, and in particular adenocarcinoma of the pancreas (59\%).

\section{Technical Features}

\section{Pre-operative}

\section{Preoperative biliary drainage}

3 studies out of 5 report the realization of a pre-operative bile drainage $(2-4)$. Of the 39 patients analysed, 19 (49\%) were treated in a jaundice context justifying pre-operative biliary drainage. No patient was drained for angiocholitis, incapacitating pruritus or before neoadjuvant treatment. Precise bilirubin thresholds indicating bile drainage were not reported. In the series by Regimbeau et al. median bilirubin levels before and after biliary drainage were $15 \mathrm{mg} / \mathrm{dl}$ (260 micromol / l) and $6 \mathrm{mg} / \mathrm{dl}$ (105 micromol / l) respectively. The rate of decrease in bilirubin level after drainage does not appear to be different in comparison to the non-cirrhotic group as well as to data from the literature. Note that biliary drainage has made it possible to reclassify 11 patients out of 13 , from Child $B$ to Child A after drainage 3. No study has evaluated the technical methods of drainage (plastic versus metal prosthesis covered, radiological percutaneous versus endoscopic).

The indications for biliary drainage before pancreatic surgery in cirrhotic patients have not been specifically evaluated. Systematic drainage in jaundice, regardless of the bilirubinaemia threshold, can be discussed in the context of optimizing liver function but should not be offered systematically. 


\section{Intraoperative}

Approach: laparoscopy or laparotomy

None of the 5 studies reported has evaluated the feasibility of the laparoscopic approach in pancreatic surgery in the cirrhotic patient.

The laparoscopic approach has not been evaluated and should not be recommended.

\section{Pyloric conservation}

None of the 5 studies reported has evaluated the value of pyloric conservation.

No recommendation can be made on the interest of pyloric conservation during a cephalic duodenopancreatectomy in the cirrhotic patient.

\section{Pancreaticogastric anastomosis versus pancreaticogejunal}

2 studies out of 5 precisely report the type of pancreatic reconstruction, with 20 pancreaticogastric anastomoses versus 17 pancreaticjejunal $(2,3)$. No comparison was made on the influence of the type of anastomosis on the occurrence of complications. Furthermore, the intubation of the trans-anastomotic Wirsung canal by a drain has not been evaluated.

No recommendation can be made on the choice of a type of pancreatic anastomosis after cephalic duodenopancreatectomy in the cirrhotic patient.

\section{Abdominal drain}

3 out of 5 studies report the use of abdominal drainage $(1,2,4)$. The type of drainage is only specified in 2 studies [Passive drainage, $\mathrm{n}=4$ (2), suction drainage, $n=4$ (4)]. The impact of drainage on postoperative complications has not been studied in any of the studies. The infection of the ascites fluid can be detected by a count of the ascites fluid as in the other surgical indications in the cirrhotic.

The course of action relating to abdominal drainage in the particular context of pancreatic surgery in the cirrhotic patient cannot be discussed. No recommendations can be made on issues of short-term drainage or lack of drainage.

\section{Somatostatin analogues}

In one of the 5 studies reported, somatostatin analogues are used systematically for preventive purposes. In the other 4 studies the analogues are used in patients at risk of developing a pancreatic fistula.

No recommendation can be made on the routine use of somatostatin analogues after cephalic duodenopancreatectomy in the cirrhotic patient.

\section{Short-term Surgery Results}

\section{Surgery Data}

\section{Surgery Duration}

The average operating times were, according to the studies, from 310 to 575 minutes (1-5). Among the 3 comparative studies $(1,3,5)$, only one study revealed significantly longer operating times in the cirrhotic patient $(348 \pm$ 52 versus $306 \pm 59, \mathrm{p}<0.0001)$ (1).

\section{Blood loss}

Median blood loss was reported in 4 studies and estimated between $150(100-175)$ and $850 \mathrm{ml}$ (1000-2000) (1-4). Among the 3 comparative studies, only one study showed significantly higher blood loss in the cirrhotic patient (500 (100-2500) versus $200(50-2000) \mathrm{ml}$, $\mathrm{p}<0.0001)(1)$.

\section{Post-surgery Period}

\section{Complications}

Overall and severe complications are found in 46 to $86 \%(1,3,5)$ and 47 to $51 \%(3,5)$, respectively. The complications most frequently found in postoperative pancreatic surgery for cirrhotic patients are:

- Pancreatic fistula: $11 \%$ to $19 \%$;

- Biliary fistula: 3 to $6 \%$;

- Gastroparesis: 15\%;

- Ascites, pre-existing or not at surgery: 10 to $48 \%$;

- Infection of ascites / peritonitis fluid: 16\%;

- Transient biological hepatocellular insufficiency: 3 to $14 \%$; 
- Hepatic encephalopathy: 3\%;

- Parietal complications: 19 to $21 \%$;

- Digestive haemorrhage: 6\%;

- Haemorrhage other than digestive: 3 to $9 \%$.

No case of portal thrombosis has been reported.

The reoperation rate is evaluated between 12 and $34 \%(1,3,5)$.

In 2015, Regimbeau et al. published a French multicentre series (14 centres) of cirrhotic patients having pancreatic surgery $(n=35)$. These patients were paired (2:1) with non-cirrhotic patients who had pancreatic surgery. The authors reported an increased risk of postoperative complications $(86 \%$ vs $43 \%$, p < 0.001 ), an increased risk of major complications ( $51 \%$ vs $21 \%, p=0.003)$ and the risk of postoperative death $(17 \%$ vs $5 \%$, $p=0.04)$ whereas the carcinological results were not different between the two groups (3).

\section{Hospital stay}

In the comparative studies $(1,3,5)$, the total intra-hospital stays 1 and the intensive care stay 5 were significantly increased in cirrhotic patients in one study in 3 .

\section{Mortality}

The reported post-operative mortality rates were 9 and $17 \%(1,3,5)$. Mortality rates were increased in the cirrhotic patient compared to the control group in 2 studies out of $3(1,3)$.

The mortality rate is closely correlated with the severity of the underlying liver disease and the existence of portal hypertension, which will be discussed below.

The cirrhotic patient treated for cephalic duodenopancreatectomy is at risk of severe complications and significantly greater mortality. His stay, including in intensive care, seems longer. The data in the literature are not robust enough to assert the impact of cirrhosis as a risk factor for pancreatic fistula.

\section{Risk Factors for Morbidity and Mortality}

\section{Child-Pugh score}

Of the 142 patients operated on, from the 5 studies selected, 17 patients (12\%) were ChildPugh B. One comparative study out of 3 evaluated the impact of the Child-Pugh score on the postoperative period. The authors report a Child-Pugh B score predictive of postoperative hepatic failure (36\% versus $8 \%$ for Child-Pugh A patients; $p=0.04$ ) and severe complications (91\% versus 33\% for Child-Pugh A patients; p <0.001) (3). In this series, the specific analysis of the Child-Pugh B patient subgroup, the overall and severe complications rates were $100 \%$ and $91 \%$ respectively and the mortality rate was $55 \%$.

\section{MELD score}

The MELD score was only specified in 2 out of 3 comparative studies. Regimbeau et al. and Warnick et al. reported a median MELD score of $10(4-36)$ and an average of $11 \pm 5$, respectively $(3,5)$.

Only one study evaluated the impact of the MELD score on postoperative operations (5). A MELD score $>15$ was significantly discriminating for the occurrence of postoperative complications ( $87.5 \%$ versus $62.5 \%)$. Although the prediction of the risk of mortality according to the MELD score is less precise with regard to the small numbers, the risk seems discriminating for a score of MELD > 20 (33\% versus $7 \%)$.

\section{Portal hypertension}

Portal hypertension was defined according to the BCLC criteria 6. Pressure measurements were not carried out pre-operatively in a systematic manner. Two comparative studies out of 3 reported the existence or not of portal hypertension in a precise manner $(1,3)$. Only one study evaluated the impact of portal hypertension on postoperative procedures (1). The existence of portal hypertension in operated cirrhotic patients significantly increased the risk of bleeding [1000 (200-2500) versus $300(100-2500) \mathrm{ml}, \mathrm{p}=0.001]$ and intraoperative transfusions $(p=0.02)$. The mortality rate was higher in the group with portal hypertension but not significantly $(25 \%$ versus $7.8 \%)$.

The place of TIPS known as preventive or 
"neoadjuvant" was not evaluated in these studies $(7,8)$.

The scores evaluating the underlying hepatopathy are correlated with the postoperative medical complications relating to cirrhosis with no obvious described impact on the surgical complications of pancreatic surgery. Child-Pugh and MELD scores should be used to assess risk and guide operative decision. Child-Pugh classes $B$ and a MELD score value greater than 15 are associated with higher morbidity and mortality.

The degree of portal hypertension must be precisely assessed pre-operatively to estimate the risk of bleeding complications. No recommendation can be made on the TIPS site, but it must be discussed on a case-by-case basis.

\section{Long-term Results: Survival, Adjuvant Therapy, Quality of Life}

Long-term survival data are only available in 2 out of 3 comparative studies $(1,3)$. Without distinguishing the underlying aetiology, El Nakeeb et al. report medians of reduced overall survival in the cirrhotic patient (19 versus 24 months, $p=0.009$ ) (1).

In the study by Regimbeau et al. overall survival without recurrence at 3 years is equivalent (44 versus $50 \%$ and 34 versus $18 \%)$. Note that in this series of duodenopancreatectomy for pancreatic cancer in cirrhotic patients, access to adjuvant treatment was possible in $76 \%$ of cases without difference from the group without cirrhosis (3).

There is no quality of life study.

In the case of suitable selection of cirrhotic patients who are candidates for pancreatic surgery, long-term survival seems to be equivalent to the non-cirrhotic group. No risk factors for long-term survival have been reported.

\section{Optimization before Surgery of the Cirrhotic Patient}

There are no studies interested, in the context of pancreatic surgery, in preoperative optimization and rehabilitation (nutritional status, exercise rehabilitation, physiotherapy, anti-thrombotic prophylaxis, antibiotic prophylaxis, prevention of hepatorenal syndrome).

No specific recommendation can be made on the preparation of the cirrhotic patient for pancreatic surgery. In the case of portal hypertension, the establishment of a TIPS can be discussed, although its benefit has not been demonstrated.

\section{Conclusion}

Cirrhotic patients who are candidates for pancreatic surgery must be properly selected, cirrhosis exposes them to a higher risk of postoperative morbidity and mortality. These conclusions should be tempered by the low level of evidence (retrospective studies), and the small number of studies and patients included in each study.

\section{Conflict of Interest}

The authors declare no conflicts of interests.

\section{References}

1. El Nakeeb A, Sultan AM, Salah T, El Hemaly M, Hamdy E, Salem A, et al. Impact of cirrhosis on surgical outcome after pancreaticoduodenectomy. World J Gastroenterol. 2013;19(41):7129-37.

2. Fuks D, Sabbagh C, Yzet T, Delcenserie R, Chatelain D, Regimbeau JM. Cirrhosis should not be considered as an absolute contraindication for pancreatoduodenectomy. Hepatogastroenterology. 2012;59(115):881-3.

3. Regimbeau JM, Rebibo L, Dokmak S, Boher JM, Sauvanet A, Chopin-Laly $X$, et al. The short- and long-term outcomes of pancreaticoduodenectomy for cancer in Child A patients are acceptable: a patient-control study from the Surgical French Association report for pancreatic surgery. J Surg Oncol. 2015; 111(6):776-83

4. Sethi $H$, Srinivasan P, Marangoni G, Prachalias A, Rela M, Heaton $\mathrm{N}$. Pancreaticoduodenectomy with radical lymphadenectomy is not contraindicated for patients with established chronic liver disease and portal hypertension. Hepatobiliary Pancreat Dis Int. 2008; 7(1):82-5.

5. Warnick P, Mai I, Klein F, Andreou A, Bahra M, Neuhaus P, et al. Safety of pancreatic surgery in patients with simultaneous liver cirrhosis: a single center experience. Pancreatology. 2011;11(1):24-9.

6. Bruix J, Sherman M, American Association for the Study of Liver D. Management of hepatocellular carcinoma: an update. Hepatology. 2011;53(3):1020-2.

7. Azoulay D, Buabse F, Damiano I, Smail A, Ichai P, Dannaoui M, et al. Neoadjuvant transjugular intrahepatic portosystemic shunt: a solution for extrahepatic abdominal operation in cirrhotic patients with severe portal hypertension. J Am Coll Surg. 2001;193(1):46-51.

8. Schlenker C, Johnson S, Trotter JF. Preoperative transjugular intrahepatic portosystemic shunt (TIPS) for cirrhotic patients undergoing abdominal and pelvic surgeries. Surgical endoscopy. 2009; 23(7):1594-8. 